\title{
The Economic and Social Consequences of Tax Havens in the World
}

\author{
Gizela Lénártová ${ }^{*}$ \\ ${ }^{1}$ University of Economics in Bratislava, Faculty of Business management, Department of Corporate \\ Finance, Dolnozemská 1, 85104 Bratislava, Slovak Republic
}

\begin{abstract}
The tax havens in the world have become the global phenomenon related tax avoidance, tax fraud and evasion and money laundering. The aim of the paper is to analyze their scope and to assess economic and social consequences of their existence in the world society, world economy, international and national tax systems. Many analyzes of the current situation and reported cases show that tax havens are threatening the stable development of the world economy, causing negative consequences of the economic, social, security and humanitarian nature of the global scale. Combating tax avoidance, tax fraud and evasion through tax havens must be stronger and more effective all around the world.
\end{abstract}

\section{Introduction}

Globalization significantly affects all ongoing processes in the world economy, while its positive and negative consequences can be observed throughout society. Piketty [1] has analyzed the current problems of the world economy, examining the causes of inequality, and his former doctoral student Gabriel Zucman [2] has focused on tax havens in the world. Tax havens are used for a variety of purposes, in particular to achieve tax savings, exploit anonymity, and protect assets and hide wealth. Tax savings may or may not mean tax evasion. Sometimes it is about tax avoidance. There is no big difference between them. This depends on the specific jurisdiction, as the concepts of tax evasion and tax avoidance are distinguished in tax legislation and criminal law. Many authors defined a tax evasion as a tax reduction, which is a criminal offense. However, advanced tax jurisdictions consider not only tax evasion but also tax avoidance unacceptable. A series of transactions in which tax legislation is abused leads to unacceptable tax avoidance. Krištofík [3] states that tax savings are among the most common motives for using tax havens, while he further states that the category of taxes (international tax planning and international tax optimization) is often examined from multiple points of view and according to different criteria. According to Graham and Tucker [4], many tax legislative provisions provide incentives or discourage companies from making certain decisions. But some inadequate incentives like a direct support are similar to tax avoidance. According to Ozili [5] factors encouraging tax evasion are: high tax rates, tax evasion sophisticated technologies, weak tax enforcement strategies, inaccurate tax data/records, booming tax avoidance industry, corruption, inadequate

*gizela.lenartova@euba.sk 
collection mechanism and non-transparency, self-employed income and other factors. Other factors that encourage tax evasion may include excessive tax burden, lack of honesty in the government, perceived unfairness, tax authorities' poor institutional infrastructure and responses, financial benefits of evading taxes, perceptions of inequality, low level of trust in tax authorities, perceived poor use of tax revenues, poor treatment of taxpayers, corruption in government, increase in banks' offshore activities with non-financial companies connected to banks, etc.

The term "tax haven" comes from the English term "tax haven", which refers to countries (territories) with a minimum, respectively no taxation. These are countries with non-standard, very advantageous tax regimes focused on attracting foreign capital to their territory. Tax havens are the target area of the so-called tax planning of many entrepreneurs - individuals or large business entities. Thus, a large proportion of the funds that are initially taxed in the country of the source of this income is spilled from the world. Domestic countries thus lose a large proportion of their tax revenues in their domestic government budgets. In addition to the term 'tax haven', the term 'the offshore financial center' (THOFC) is often used in the literature [6], means a country "off the coast" to designate smaller islands outside the territories - off the coasts of developed countries. Over time, these islands, especially from the United States and the United Kingdom, began offering various kinds of benefits to investors from developed countries around the world in order to attract foreign capital to their territory. Offshore centers are therefore countries that, in addition to a special tax regime, also offer other services and exceptional trading and business conditions for investors on their territory, which include quality infrastructure, a stable legal environment, a reliable banking system, a functioning judicial system, low administrative restrictions on the simple and fast establishment of companies, etc. These conditions and unmistakable advantages have enabled them to become major global financial centers. In the last decades of the 20th century, the offshore industry has developed and it is estimated that the volume of liquid capital flowing through these countries accounts for approximately $70-80 \%$ of private liquid capital worldwide. With regard to offshore centers, serious problems of a global nature are also coming to the forefront. Used only as tax havens, these territories did not cause such concern to experts of international institutions (e.g. OECD) and did not pose such serious threats to international development as in the last decades of the 20th century. The point is that these territories (whether we call them tax havens or offshore centers) have been used by criminals for money laundering in addition to tax planning and these areas are soaked in by the dirty money economy of the world (drugs, prostitution, kidnapping, financial fraud, terrorism, trade in arms and strategic raw materials). This is reason why these teritories are a real threat for stability in the world.

\section{The aims and methods}

The aim of this paper is to characterize the nature of tax havens, to investigate their extent and effects on whole of society, next to evaluate the negative consequences of their existence in society and economy in the world and in national tax systems. The methods used are normative methods of analysis of tax legislation and legal measures and regulations of G20, OECD, EU and other international institutions relevant to the given topic, comparative methods, abstraction, inductive and deductive methods. Effectiveness of taken measures were evaluated by normative methods and negative consequences in national and international context were summarised on the base of methods of synthesis. 


\section{Results and Discussion}

Tax havens have been the subject of research and studies by economists around the world for many decades. They examine issues of domestic tax legislation, international treaties to eliminate double taxation, the application OECD documents, EU directives and their impact on the decision making of individuals and companies to use tax havens.

Hong and Smart [7] are exploring the use of various tax structures - the use of preferential debt financing, royalties and dividend policy, intercompany trade. Desai, Foley and Hines [8] have shown in their studies that branches in countries with high tax rates use much more to finance their foreign capital investments than equity. They also discussed tax rate issues, finding that lower tax rates abroad stimulate US companies to use indirect ownership structures in their foreign direct investment. This is related to the increasing share of multinationals investing through entities in third countries. Studies suggest that pre-tax profitability negatively correlates with local tax rates, resulting in active tax avoidance and low connectivity, respectively none between the place where economic activity took place and the place where profits are allocated. In his regression analysis, Weyzig [9] confirmed that international double taxation treaties are key determinants of foreign direct investment directed through the Netherlands. Other studies [10] point out that some entities including MNE not only pursue tax benefits but also other criteria when setting up companies in advantageous jurisdictions.

Zucman [11] presents the results of research that focused on tax havens around the world and their role in deepening inequalities. His sharp criticism is mainly Switzerland, which hides more than $1 / 3$ of the wealth of the world. The analysis of tax havens is based on data from central banks of different countries, comparing the financial liabilities of banks with financial assets and the difference between them is hidden in tax havens in various forms, e. g. in the form of mutual fund shares, in particular in Luxembourg, the Cayman Islands and Ireland.

Table 1. The World's Offshore Financial Wealth

\begin{tabular}{|l|c|c|c|}
\hline & $\begin{array}{c}\text { Offshore wealth } \\
\text { (\$ billions) }\end{array}$ & $\begin{array}{c}\text { Share of } \\
\text { financial } \\
\text { wealth held } \\
\text { offshore }\end{array}$ & $\begin{array}{c}\text { Tax revenue } \\
\text { loss } \\
\text { (\$ billions) }\end{array}$ \\
\hline Europe & 2,600 & $10 \%$ & 75 \\
\hline United States & 1,200 & $4 \%$ & 36 \\
\hline Asia & 1,300 & $4 \%$ & 35 \\
\hline Latin America & 700 & $22 \%$ & 21 \\
\hline Africa & 500 & $30 \%$ & 15 \\
\hline Canada & 300 & $9 \%$ & 6 \\
\hline Russia & 200 & $50 \%$ & 1 \\
\hline Gulf Countries & 800 & $57 \%$ & 0 \\
\hline Total & 7,600 & $8,0 \%$ & 190 \\
\hline
\end{tabular}

Source: Zucman, G. The Hidden Wealth of Nations. The Scourge of Tax Havens (2015)

Notes : Author's computation: Offshore wealth includes financial assets only (equities, bonds, mutual fund shares, and bank deposits). Tax revenue losses only includ the evasion 
of personal income taxes on investment income earned offshore as well as evasion of wealth, inheritance, and estate taxes.

According to Zucman, up to $\$ 7.6$ trillion of privately owned world wealth was stored in the tax havens of the world in 2014 , which represents about $8 \%$ of the world's net financial wealth. The author states that this is an estimate because the difference between financial liabilities and financial assets in banks does not include the value of assets in the form of works of art, jewellery and real estate. Out of $\$ 7.6$ trillion, $\$ 1.5$ trillion was declared, $\$ 6.1$ trillion was undeclared, of which annual tax revenue loss was $\$ 190$ billion. (approximately $\$ 125$ billion for interest income, dividend and income tax, $\$ 55$ billion for inheritance tax and $\$ 10$ billion for wealth tax).

In 2014, the International Association of Investigative Journalists (ICIJ) revealed hundreds of multinationals that had collusion with some European governments. The cases revealed include: Apple in Ireland did not have to pay $12.5 \%$ tax; apply an effective tax rate of 0 ; Amazon in the UK reported minimal revenue as UK online store revenue flowed through a Luxembourg branch that reimbursed the British for the cost of distributing goods; Starbucks in the Netherlands has had unjustified tax benefits since 2008 - it has not paid any taxes for 4 years; Fiat in Luxembourg has unjustifiably reduced its tax liability by EUR 20-30 million since 2012 due to the tax advantage. McDonald's in Luxembourg has not paid corporate tax on European and Russian subsidiaries for more than 8 years $(\$ 500$ million). The European Commission has assessed these practices as unlawful State aid.

In 2016, the International Association of Investigative Journalists (ICIJ) published, under the name Panama Papers [12], a database of the Panama consulting firm Mossack Fonseca with 11.5 million documents with 200,000 companies and individuals (presidents, diplomats, businessmen, athletes, artists, royal family members) focusing on the transfer of funds to tax havens. A portion of the company's clients in its 40-year history have used the company for tax avoidance, Money laundering, hiding money from corruption, illegal arms trading, diamonds. It has been estimated that since 1977 hundreds of billions of euros have "flowed" through this company. The world's leading economists as well as international institutions responded to the Panama Papers, such as OECD's BEPS initiative and the OECD Black List of non-cooperating countries. The EU has adopted ATAD Directive and the Directive on the automatic mandatory exchange of information for multinational companies in the EU Member States. Since 1 January 2016, multinationals have been reporting in the EU Member State where the Group's principal entity is located for tax purposes: amount of income, profit before tax, tax paid, declared capital, retained earnings, tangible assets, number of employees by country where they do business. Reports shall be provided to other Member States where the group is located.

In 2017, ICIJ published a Paradise Papers [13] - database of 13.4 mil. documents of two offshore companies Apple based in Bermuda and Estera based in Singapore. The records include emails, contracts, bank records of more than 25,000 people-related businesses in 180 countries around the world. They uncover increasingly sophisticated and accounting operations and methods of how huge multinational corporations benefit from tax havens, while revealing the links of personal wealth and large corporations to the worldleaders.

Paradise Papers contains 200 names of Slovaks. According to the authors Ištok (ed.) [14] between 2005 and 2014 there was a dramatic increase in the number of Slovak companies that moved their registered offices to jurisdictions in tax havens. In 2005 there were 1510 of these companies, in 2014 the number increased to 4362 Slovak enterprises, which represents an increase of $189 \%$. The most used tax havens by entrepreneurs from Slovakia are in the Netherlands 1154, in the USA 1028, in Cyprus 750, in Luxembourg 393, in Seychelles 205, in the Isle of Man 155. The most common motives for the use of tax havens are tax savings. 


\subsection{Consequences of tax havens in national and international context}

In response to these ICIJ publications, 300 world economists from more than 30 countries around the world have decclared that tax havens distort the functioning of the world economy. However, the negative consequences of their existence are much wider. These are not only economic, but also social and security implications in a national and international context, which overlap, interact, multiply their effects in a negative synergic effect.

As a results of study of tax havens in the world we can summarize consequences:

1. Economic consequences and threats: decrease in revenues to the domestic budgets; the lack of funds to finance the needs of the state - for education, health, (hospitals, prevention of diseases and epidemics, fight against pandemics); the lack of funds for the public sector, environmental protection, development programs, support for science, research and development, business support and job creation etc.; the lack of funds to redistribute wealth and mitigate inequalities; tax havens distort the functioning of the world economy and the national economy of the world; tax havens destroy the world economy and national economies and cause economic and financial instability.

2. Social consequences and threats: deepen inequalities between individuals and economic actors in the economic and social context, as well as increasing inequalities in opportunities to learn, live and work in dignity; the increase in poverty and the resulting consequences of low levels of education and disease prevention, increased frustration of the population, growth in crime in society; decrease of legal awareness of the population.

3. Security implications and threats: the loss of transparency in the financial sector increases the risk of using funds for crime with negative social consequences, for terrorism and for threats to human security.

4. Political and social consequences and threat: the lack of transparency of national and national public finances makes it possible to link business and investment funds (net money) with funds from crime (money laundering), linking with world politics threatens the democratic foundations of states in the world, linking financial power and political power and non-transparency allow to misuse and threaten the foundations of democracy and human civilization.

5. Humanitarian consequences - humanitarian disasters: according to the world's leading economists, the existence of tax havens is literally a tragedy for developing countries. ActionAid estimates that developing countries will lose about $€ 160$ billion in tax havens. The Australian mining company has saved so much money on taxes in Malawi, that would be enough to pay 39,000 teachers or 8,500 doctors a year. According to the UN, the Democratic Republic of Congo is one of the least developed countries in the world, with nearly half of the children suffering from malnutrition, but Glencore (copper mines) and Gentler (mining tycoon - a close friend of the Congolese president) invested more than half a billion dollars in Gertler's offshore companies. Its profit is estimated at 67 mil. dollars. All these negative consequences mean a serious threat to our society. This is the main reason why action needs to be taken against them.

Fazio [15] wrote in the Corona-time crisis "It has become evident that those who do not pay their taxes are not only guilty of a crime, but guilty of the most serious crime - murder: if the beds and the respirators are not there they are partly to blame".

\subsection{Evaluation of effectiveness and success of the fight against tax evasion through tax havens}

The OECD uses four basic criteria to identify tax havens: 1. no or low tax burden, 2 . ineffective exchange of tax information, 3. absence of transparency, 4. investment primarily 
on the basis of tax incentives and savings without real economic activity. In addition to these 4 criteria, an important criterion is used to identify a tax haven - the placement of jurisdiction in the FSI (Financial Secrecy Index) ranking, which assesses, among other things, the degree of confidentiality, respectively transparency and use of preferential tax regimes. OECD publishes black and grey lists of countries that are often updated. There are many paradoxes in the fight against tax havens [16], one of them is that some OECD member states, resp. the EU is ranked in negative FSI rankings (e.g. USA, Luxembourg or UK).

The G20 leaders declared the "end of banking secrecy" in the world at the April 2009 summit. It should be noted that the enforcement of this measure is difficult and in real life there has been only a slight restriction on banking secrecy. Persuasion is not enough. Many tax havens agree to cooperate, often only formally, and provide information sporadically. The result is the absence of a strong tool to break banking secrecy and force the exchange of information. The sanctions applied so far are not sufficiently effective. Weichenrieder and $\mathrm{Xu}$ [17] have derived positive welfare effects of a crackdown on tax haven secrecy.

Since 2010, the US has been conducting an automatic exchange of information between foreign banks and the IRS through the Foreign Account Tax Compliance Act (FATCA). This measure met with great criticism.

In 2013, the OECD adopted a Global Automatic Exchange of Information (GAEI) document to ensure global automatic exchange of information (GATCA). It should be implemented as a global standard by the end of 2020. Key tax havens have announced that they will participate in this system. Overcoming financial opacity is still ineffective. Most accounts in tax havens are hidden in shell companies, foundations, funds, which are intended to legally or illegally break connections and hide the real wealthy money owners. Only a small fraction of taxpayers who do not have access to shell companies are involved in the automatic exchange of information, and it is only a small fraction of the data provided in the automatic exchange of information. Tax institutions do not have the means to verify the whole system and to set up a system of control and verification on 'provocateurs and denunciators' is a weak strategy to fight.

In November 2016, the OECD approved the Multilateral Instrument (MLI), which allows rapid revision of bilateral double taxation treaties and the implementation of adopted BEPS (Base Erosion and Profit Shifting) measures. The multilateral instrument will help to respond better and faster to inappropriate practices in the field of aggressive tax planning of multinationals.

The EU has not taken significant and open action directly against tax havens in the last decades of the 20th century. Based on analyses, EU legislation has so far been aimed at combating tax evasion and fraud, particularly in the field of VAT, aggressive tax planning and tax avoiding. At the beginning of $21^{\text {st }}$ Century on the basis of the BEPS initiative, the EU has taken some measures to combat tax avoidance, in particular ATAP and ATAD. The latest proposals of the European Commission are focused on: automatic exchange of information and new transparency rules (new Directive in force), a new proposal for a directive on tax intermediaries, the adoption of the Fifth Anti-Money Laundering Directive, the creation of a black list of tax havens (following the OECD list).

The increasing pressure of the EU in the fight against tax havens can be viewed positively. In the EU Member States, the automatic exchange of information in the area of taxation and Money laundering has been improved both in the legislative area and in the use of IT systems in tax practice. The creation of a black and grey lists of tax jurisdictions includes 4 phases: country selection, screening, listing and monitoring. In 2017, ministers of EU Member States agreed at a meeting of ECOFIN on a black list of tax havens. This was the result of an assessment of 92 tax jurisdictions out of a total of 213 countries according to three main criteria: transparency of the tax system, fair taxation, and engaging 
the country in international cooperation to combat tax fraud. Countries that did not meet the criteria during the past period have reached the black list [18]. These are 17 states that have the status of non-cooperating tax jurisdictions: American Samoa, Bahrain, Barbados, Grenada, Guam, South Korea, Macau, Marshal Islands, Mongolia, Namibia, Palau, Panama, Saint Lucia, Samoa, Trinidad and Tobago, Tunisia, United Arab Emirates (UAE). In addition, 47 jurisdictions have been defined in grey list which must improve transparency, eliminate harmful tax competition, introduce the required criteria and implement OECD BEPS, of which 8 are so-called 'hurricane countries' have longer time to implement the measures.

In 2019 in group of non-cooperating tax jurisdictions there were 8 countries: American Samoa, Fiji, Guam, Oman, Samoa, Trinidad and Tobago, US Virgin Islands, Vanuatu. In February 2020 four other states have been included in the black list: Cayman Islands, Palau, Panama and Seychelles.

Several EU Member States support strict measures against black and grey countries, including upcoming to limit financial support from the European Union, the World Bank or the IMF. Research studies [19] documented that tax reforms themselves cannot to solve the tax avoidance and tax evasion through tax havens. Many experts claim that without sanctions and strict measures, which include raising the withholding tax, the possibility of non-deducting costs for companies, various audits and more, tax havens around the world will not be reduced. In its report, the international non-profit organization Oxfam drew attention to negative practices in the process of blacklisting. We mean the presence of strong political and economic pressures in blacklisting. As a result, the lists do not include states that have been involved in revelations and tax scandals over the past five years. According to Oxfam, another 18 countries, including EU Member States, which are among the largest tax havens in the world, should be blacklisted. Oxfam included the Netherlands, Ireland, Luxembourg and Malta. After frequent updates black and grey list of tax havens the Oxfam international [20] in press release wrote that EU' tax havens blacklist "more like a whitewash". The question arises, what is the real willingness of world politicians to address the problem of tax havens in the world and what will be the political continuity of the measures?

\section{Conclusion}

Tax havens negatively affect the world economy. The aim of this paper was to characterize the nature and extent of tax havens, to identify the negative consequences of their existence in the world economy and in national tax systems. The analyses show that tax havens are causing major tax evasion, which are missing from national budgets. The uncovered cases of Lux Leaks, Panama Papers, Paradise Papers documents show that tax havens are a big threat to the stable development of the world economy, causing negative consequences of the economic, social, security and humanitarian nature of the global scale. Turner [21] wrote "If one industry deserves to collapse in this crisis, it is tax avoidance". The initiatives and measures taken so far by the OECD and other international institutions and economic integration clusters are numerous but not yet effective. Therefore, the fight against tax havens must be more vigorous, stronger and more effective for all competent professionals and politicians internationally and nationally.

This paper is a partial outcome of the project of VEGA MŠ SR VEGA 1/0007/2019 "Allocation of assets in the environment of low interest rates in financial and non-financial corporations in Slovakia" in the range of $100 \%$. 


\section{References}

1. T. Piketty, Capital in the Twenty-first Century. s.237. (2014)

2. G. Zucman: The Hidden Wealth of Nations. The Scourge of Tax Havens. (2015)

3. P. Krištofík, M. Ištok, G. Nedelová, Motívy zakladania onshore a offshore společností slovenskými podnikmi v roku. Politická ekonomie 65, 2, 198-216 (2014)

4. J. R. Graham, A. L. Tucker, Tax Shelters and Corporate Debt Policy. Journal of Financial Economics, 81, 3, 563-594 (2006)

5. P. K. Ozili. Tax evasion and financial instability. Journal of Financial Crime (2019) also in MPRA Munich Personal RePEc Archive, PRA Paper No. 88430 (2018)

6. T. Sigler, K. Martinus, I. Iacopini, B. Derudder, The role of tax havens and offshore financial centres in shaping corporate geographies: an industry sector perspective. Journal Regional Studies. (2019)

7. O. Hong, M. Smart, M. In Praise of Tax Havens: International Tax Planning and Foreign Direct Investment. European Economic Review 54, 1, 82-95 (2010)

8. A. Desai, F. Foley, J. Hines, A Multinational Perspective on Capital Structure Choice and Internal Capital Markets. The Journal of Finance 59, 6, 2451-87 (2004)

9. F. Weyzig, Tax Treaty Shopping: Structural Determinants of Foreign Direct Investment routed through the Netherlands. International Tax and Public Finance 20, 6, 910-937 (2013)

10. N. Brueller, A. Carmeli, G. Markman, Linking merger and acquisition strategies to post-merger integration: A configurational perspective of human resource management. Journal of Management, 44, 5, 1793-1818 (2018)

11. G. Zucman: The Hidden Wealth of Nations. The Scourge of Tax Havens. (2015)

12. F. Obermaier, B. Obermayer, U. Schäffer. Panama Papers, Secret of Dirty Money. Süddeutsche Zeitung, (3.4.2016) https://panamapapers.sueddeutsche.de/en/

13. F. Obermaier, B. Obermayer, Paradise Papers, Süddeutsche Zeitung, (6.11.2017) https://www.sueddeutsche.de/thema/Paradise_Papers

14. M. Istok, M. Kanderova, P. Kristofik, K. Scerba, International Corporate Structuring of Slovak Companies Using Tax Havens. Journal of Competitiveness, 11, 1, 22-40 (2019)

15. F. Fazio, Le cose che sto. La Repubblica, 16 March 2020 https://www.repubblica.it/cronaca/2020/03/16/news/le_cose_che_ho_imparato251384470/, [accessed 1.04.2020]

16. P. Krištofík, M. Ištok, G. Nedelová, Motívy zakladania onshore a offshore společností slovenskými podnikmi v roku. Politická ekonomie 65, 2, 198-216 (2014)

17. A. J. Weichenrieder, F. Xu, Are Tax Havens good? Implication of the crackdown on secresy. Journal of Economics, 127, 2147-160 (2019)

18. http://europa.eu.rapid/press-release_MEMO-175122_en.htm [accessed 31.03.2020]

19. J. Nebus, Will tax reforms alone solve the tax avoidance and tax haven problems? Journal of International Business Policy, Palgrave Macmillan, 2, 3, 258-271 (2019)

20. OXFAM International, EU's tax havens blacklist' 'more like a whitewash', Press releases 12.3.2019. https://www.oxfam.org/en/press-releases/eus-tax-havens-blacklistmore-whitewash [accessed 30.03.2020]

21. G. Turner, Tax avoiders will receive coronavirus bailouts - we must redress this injustice. The Guardian 27.3.2020

https://www.theguardian.com/world/commentisfree/2020/mar/27/tax-avoiderscoronavirus-bailouts [accessed 1.4.2020] 